\title{
Has the Financial Crisis Changed the Business Cycle Characteristics of the GIIPS Countries?
}

\author{
Andrew Hughes Hallett ${ }^{{ }^{*}}$ \& Christian Richter ${ }^{2}$ \\ ${ }^{1}$ School of Public Policy, George Mason University, Fairfax, VA, USA \\ ${ }^{2}$ Business School, University of Bedfordshire, Luton, UK \\ * Correspondence: Andrew Hughes Hallett, George Mason University, School of Public Policy, 4400 \\ University Drive, Fairfax, VA 22030, USA. Tel: +1-703-933-9123; Email: ahughesh@gmu.edu \\ DOI: $10.12735 /$ je.v2i4p25 URL: http://dx.doi.org/10.12735/jfe.v2i4p25
}

\begin{abstract}
Since the financial crisis erupted in 2008, the governments of Portugal, Ireland, Italy Greece and Spain (GIIPS) find themselves in a position where financing their debts has become increasingly difficult. As a result, these governments reduced government expenditure and/or increased taxes in order to reduce their deficits. Hence, whilst other countries in the Eurozone - notably Germany enjoyed a recovery from the financial crisis, the GIIPS countries only just started to recover. It is therefore no surprise that the business cycles of the northern and southern European countries diverged, and there was and still is a real fear of deflation. This poses a risk for the Eurozone, as it makes the common monetary policy less effective.

In this paper we analyse these business cycles in detail. We ask whether the financial crisis has changed the characteristics of the business cycles of the GIIPS countries. For example, the austerity measures in Greece may lead to a convergence of government spending between Germany and Greece and to greater convergence of business cycles in both countries. If it does, then there is some hope that the common monetary policy will return to being effective in the future. But it may not. The austerity measures could also lead to greater divergence between Greece and Germany, in which case leaving the monetary Union would not only be beneficial for Greece. It might be unavoidable.
\end{abstract}

JEL Classifications: C22, C29, C49, F43, O49

Keywords: time-frequency analysis, coherence, growth rates, business cycle

\section{Introduction}

This paper asks and analyses whether the financial crisis has changed the business cycle characteristics of the GIIPS countries (Portugal, Ireland, Italy, Greece and Spain). In doing so, it focuses on what effect the financial crisis had on the convergence of business cycles in the Eurozone. This is an important question: if the business cycle characteristics of one Eurozone country changes, this has consequences for the other Eurozone countries unless all other business cycle characteristics change in the same way. 
The financial crisis, and the new fiscal policies associated with it, could theoretically lead to greater convergence of business cycles as the GIIPS countries behave more like their Northern neighbours. Or they could drift further away because the austerity measures which are only taken in those countries would lead to recession and hence further divergence among the business cycles.

This is a very difficult area to investigate because there is no consensus that business cycles had converged prior to the financial crisis. So to what extent are different countries' growth cycles more correlated across Europe than they were before? Is there evidence of cyclical convergence at the business cycle frequency (the focus for policy purposes), or at any other frequencies in the Euro area? Does that imply a common European cycle? Cyclical convergence is an essential condition for the success of a single currency (the Eurozone); or for pegging to another currency and its monetary policies ("dollarization").

As mentioned above, a selective reading of the literature could lead to almost any conclusion. We therefore add a prior question: how should we go about measuring cyclical convergence in this context? In this paper we show that time-frequency analysis can be used to answer these questions, even when data samples are small and where structural breaks and changing structures are an important part of the story. We need a spectral approach in order to be able to determine the degree of convergence at different frequencies/cycles. Inconclusive results obtained in the past may have been the result of using a correlation analysis which averages the degree of convergence across all frequencies. Two economies may share a trend or short terms shocks, but yet show no coherence between their business cycles for example.

To give a sense of the problem, neoclassical growth models show that every economy approaches a steady-state income level determined by the discount rate, the elasticity of factor substitution, the depreciation rate, capital share, and population growth. Once at the steady-state, the economy grows at a constant rate. Thus, to the extent that the determinants of the steady-state are similar across economies, convergence is to be expected. But if these deter-minants are different, the economies will not converge. Thus, Mankiw, Romer, and Weil (1992), Dowrick and Nguyen (1989), Wolff (1991), Barro and Sala-I-Martin (1991; 1992), Quah (1993) find evidence of convergence for a sample of OECD countries at similar levels of development over the years 19601985. But they reject that convergence hypothesis in a wider sample of 75 economies whose structures and degree of uncertainty vary a good deal more. Similarly, Chauvet and Potter (2001) report that the US business cycle was in line with the G7 from the mid-1970s, but then diverged thereafter. Likewise Stock and Watson (2002; 2003), Hughes Hallett and Richter (2006) find divergence caused by structural breaks, and argue that cyclical convergence is a global rather than regional phenomenon.

As far as the Eurozone is concerned, Artis and Zhang (1997) and Frankel and Rose (1998) have argued that if exchange rates are successfully pegged, and trade and financial links intensify, then business cycles are likely to converge. On the other hand, Inklaar and de Haan (2000) do not find any evidence for a European business cycle in practice. Similarly, Gerlach (1989), Baxter and Kouparitsas (2005), Doyle and Faust, (2003), Kalemli-Ozcan, Sorensen, and Yosha (2001) and Peersman and Smets (2005) find no evidence of greater convergence among the OECD economies as exchange rates stabilise or trade increases. All these results suggest a time-varying approach is going to be necessary as the time-varying approach can distinguish cycles which are in common between countries from those which are not. Furthermore our analysis will also show if there is a systematic change of business cycle characteristics towards common cycles, which is what the term 
"convergence" implies. It is therefore necessary to use a time-frequency analysis if we are to analyse an emerging convergence among economies ${ }^{1}$.

The studies cited above also make it clear that the results in this literature are sensitive to: a) the choice of coherence measure (correlation, concordance index); b) the choice of cyclical measure (classical, deviation or growth cycles); and c) the detrending measure used (linear, HodrickPrescott filter, band pass etc.). This sensitivity to the detrending technique is a problem highlighted in particular by Canova (1998). The advantages of using a time-frequency approach are therefore:

i) It does not depend on any particular detrending technique, so we are free of the lack of robustness found in many recent studies.

ii) Our methods also do not have an "end-point problem" - no future information is used, implied or required as in band-pass or trend projection methods.

iii) There is no arbitrary selection of a smoothing parameter, such as in the HP algorithm, equivalent to an arbitrary band-pass selection ( Artis, Marcellino, \& Proietti, 2004).

iv) We use a coherence measure which provides more detailed information than the conventional correlation and concordance measures.

However, any spectral approach is tied to a model based on a weighted sum of sine and cosine functions $^{2}$. That is not restrictive. Any periodic function may be approximated arbitrarily well over its entire range, and not just around a particular point, by its Fourier expansion (a suitably weighted sum of sine and cosine terms) - and that includes non-differentiable functions, discontinuities and step functions. Hence, once we have time-varying weights, we can get almost any possible cyclical shape. For example, to get long expansions, but short recessions, we need only a regular business cycle plus a longer cycle whose weight increases above trend but decreases below trend (i.e. varies with the level of activity). This is important because many observers have commented on how the shape of economic cycles has changed over time in terms of amplitude, duration and slope (Harding \& Pagan, 2001; Peersman \& Smets, 2005; Stock \& Watson, 2002). Once again, a timevarying spectral approach is necessary to provide the flexibility to capture these features. Similarly it is needed if we are to accommodate, and reveal, the possibility of structural breaks which must be expected with the breakdown of the EMS, the coming of the Euro, the changes in monetary institutions, and the increasing integration and volatility of financial markets.

\section{A Technical Introduction to Time Frequency Analysis}

\subsection{Time Varying Spectra}

Spectral analysis decomposes the variance of a sample of data across different frequencies. The power spectrum itself then shows the relative importance of the different cycles in creating movements in that data, and hence describes the cyclical properties of a particular time series. It is assumed that the fluctuations of the underlying data are produced by a large number of elementary cycles of different frequencies. Furthermore, it is usually assumed that the contribution of each

\footnotetext{
${ }^{1}$ Also because structural characteristics and institutions change. It appears that cyclical correlations typically fall with the degree of industrial specialisation which increases, both in Europe and beyond, as trade and financial integration intensify (Kalemli-Ozcan et al., 2001). Then there are induced market reforms, liberalisation measures, and the extent to which policies are coordinated or made common to a group of economies.

${ }^{2}$ See also Söderlind (1994).
} 
cycle is constant throughout the sample. However, as Chauvet and Potter (2001) show for the US, business cycles cannot be assumed to be constant. Hence, the spectrum would not be constant over time due to the changing weights associated with each of the elementary cycles. A "traditional" frequency analysis cannot handle that case. We therefore focus on a time-varying frequency analysis to take these issues into account. Time-frequency analysis is based upon a "short term Fourier transform" and is widely used in engineering and sciences. Details on the short time Fourier transform can be found in Matz and Hlawatsch (2003) and Cunha and Richter (2012, 2014).

All the data collected (including the Eurozone data) are real GDP from the OECD main indicators. We use seasonally adjusted quarterly data from 1970:1 to 2012:3. For countries inside the Euro area and the Eurozone itself, GDP is expressed in Euros over the entire sample. Growth rates are then defined, using GDP data, as follows:

$$
Y_{t}=\Delta\left(\log \left(Y_{t}\right)\right)=\log \left(\frac{Y_{t}}{Y_{t-4}}\right)
$$

Next we employ a two-step procedure. As Evans and Karras (1996) point out, if business cycles are to converge, they have to follow the same AR(p) process. We therefore estimate an AR(p) process for each variable individually. That is, we estimate the data generating process of each of the growth rates separately. Then we estimate the bilateral links between the cycles in those growth rates. In order to allow for the possible changes in the parameters, we employ a time-varying model by applying a Kalman filter to the chosen AR(p) model as follows:

$$
\mathrm{y}_{\mathrm{t}}=\alpha_{0, \mathrm{t}}+\sum_{\mathrm{i}=1}^{9} \alpha_{\mathrm{i}, \mathrm{t}} \mathrm{y}_{\mathrm{t}-\mathrm{i}}+\varepsilon_{\mathrm{t}}
$$

with

$$
\alpha_{i, t}=\alpha_{i, t-1}+\eta_{i, t}, \text { for } i=0 \ldots 9
$$

and $\varepsilon_{t}, \eta_{i, t} \sim$ i.i.d. $\left(0, \sigma_{\varepsilon, \eta_{i}}^{2}\right)$, for $\mathrm{i}=0 \ldots 9$.

In order to run the Kalman filter we need to specify initial parameter values. Our initial parameter values are obtained by estimating them by OLS using the entire sample (see also Wells, 1996) ${ }^{3}$. Given these starting values, we can estimate the parameter values using the Kalman filter. We then employ a general to specific approach, eliminating insignificant lags using the strategy specified below. The maximum number of lags to start was determined by the Akaike Criterion (AIC), and was found to be nine in each case. Each time we ran a new regression we used a new set of initial parameter values. Then, for each regression we applied a set of diagnostic tests shown in the tables in Appendix 1, to confirm the specification found. The final parameter values are filtered estimates, independent of their start values.

Using the above specification implies that we get parameter values for each point in time. Hence, a particular parameter could be significant for all points in time; or at some but not others;

${ }^{3}$ Obviously, using the entire sample implies that we neglect possible structural breaks. The initial estimates may be biased therefore. The Kalman filter will then correct for this since, as Wells (1996) points out, the Kalman filter will converge to the true parameter value independently of the initial value. But choosing initial values already "close" to the true value will accelerate that convergence. Hence we employ an OLS estimate to start. But our start values have no effect on the parameter estimates by the time we get to 1990. Our results are robust. 
or it might never be significant. The parameter changes are at the heart of this paper as they imply a change of the lag structure and a change in the spectral results. We therefore employed the following testing strategy: if a particular lag was never significant then this lag was dropped from the equation and the model was estimated again. If the AIC criterion was less than before, then that lag was completely excluded. If a parameter was significant for some periods but not others, it was kept in the equation with a parameter value of zero for those periods in which it was insignificant. This strategy minimised the AIC criterion, and leads to a parsimonious specification. Finally, we tested the residuals in each regression for auto-correlation and heteroscedasticity.

The specification (2.2) - (2.3) was then validated using two different stability tests. Both tests check for the same null hypothesis (in our case a stable AR(9) specification) against differing temporal instabilities. The first is the fluctuations test of Ploberger, Krämer, and Kontrus (1989), which detects discrete breaks at any point in time in the coefficients of a (possibly dynamic) regression. The second test is due to LaMotte and McWorther Jr. (1978), and is designed specifically to detect random parameter variation of a specific unit root form (our specification). We found that the random walk hypothesis for the parameters was justified for each country (results available on request). Finally, we chose the fluctuations test for detecting structural breaks because the Kalman filter allows structural breaks at any point and the fluctuations test is able to accommodate this. ${ }^{4}$ Thus, and in contrast to other tests, the fluctuations test is not restricted to any pre-specified number of breaks. ${ }^{5}$

Once this regression is done, it gives us a time-varying AR(p) model. From this AR(p) we can calculate the Fourier transform, in order to calculate the time-varying spectrum. The basic idea is to find the spectrum of a signal $x(t)$, at time $t$, by analysing a small portion of the signal around that time.

a) Spectra: The time-varying spectrum of the growth rate series can therefore be calculated as (for examples in the engineering literature, see: Lin, 1997):

$$
P_{t}(\omega)=\frac{\sigma^{2}}{\left|1+\sum_{i=1}^{9} \alpha_{i} \exp (-j \omega i)\right|_{t}^{2}}
$$

where $\omega$ is angular frequency and $\mathrm{j}$ is a complex number. The main advantage of this method is that, at any point in time, a power spectrum can be calculated instantaneously from the updated parameters of the model (see also Lin, 1997). Similarly, the power spectrum for any particular time interval can be calculated by averaging the filter parameters over that interval. This would then result in the "traditional" spectra.

b) Cross-spectra: Returning to the second step of our analysis, we can now estimate the one to one relationship between two economies. We restrict ourselves to bilateral relationships in order to avoid multicollinearity between a series of potentially interrelated cycles.

\footnotetext{
${ }^{4}$ Note that all our tests of significance, and significant differences in parameters, are being conducted in the time domain, before transferring to the frequency domain, because no statistical tests exist for calculated spectra (the transformations may be nonlinear and involve complex arithmetic). Stability tests are important here because our spectra could be sensitive to changes in the underlying parameters. But with the stability and specification tests conducted, we know there is no reason to switch to another model that fails to pass those tests.

${ }^{5}$ The fluctuations test works as follows: one parameter value is taken as the reference value, e.g. the last value of the sample. All other observations are now tested whether they significantly differ from that value. In order to do so, Ploberger et al. (1989) have provided critical values. If the test value is above the critical value then we have a structural break, i.e. the parameter value differs significantly from the reference value and vice versa.
} 
By transferring the time domain results into the frequency domain, we can show how the relationship between two economies has changed in terms of individual frequencies. That is, we are able to investigate whether any convergence took place over time; and, if so, at which frequencies. As a measure of that relationship, we use the coherence. We then decompose the coherence in order to see whether a change in the coherence is caused by a change in the relationship between the two variables (i.e. in the ADL model below); or by a change in the data generating process itself (i.e. in the $\mathrm{AR}(\mathrm{p})$ model itself). With a time-invariant method that cannot be done. The next section outlines these ideas.

\subsection{Time Varying Cross-Spectra}

Suppose we are interested in the relationship between two variables, $\left\{\mathrm{y}_{\mathrm{t}}\right\}$ and $\left\{\mathrm{x}_{\mathrm{t}}\right\}$ say, where $\left\{y_{t}\right\}$ is the US growth rate and $\left\{x_{t}\right\}$ is a European growth rate. We assume that they are related in the following way:

$$
\mathrm{V}(L)_{t} y_{t}=A(L)_{t} x_{t}+u_{t}, u_{t} \sim i . i . d .\left(0, \sigma^{2}\right)
$$

where $\mathrm{A}(\mathrm{L})$ and $\mathrm{V}(\mathrm{L})$ are filters, and $L$ is the lag operator such that $L \mathrm{y}_{\mathrm{t}}=\mathrm{y}_{\mathrm{t}-1}$. Notice that the lag structure, $\mathrm{A}(\mathrm{L})$, is time-varying. That means we need to use a state space model (we use the Kalman filter) to estimate the implied lag structure. That is

$$
\begin{aligned}
& \mathrm{v}_{\mathrm{i}, \mathrm{t}}=\mathrm{v}_{\mathrm{i}, \mathrm{t}-1}+\varepsilon_{\mathrm{i}, \mathrm{t}}, \text { for } \mathrm{i}=1, \ldots, \mathrm{p} \text { and } \varepsilon_{\mathrm{i}, \mathrm{t}} \sim\left(0, \sigma_{\varepsilon_{\mathrm{i}}}^{2}\right) \\
& \mathrm{a}_{\mathrm{i}, \mathrm{t}}=\mathrm{a}_{\mathrm{i}, \mathrm{t}-\mathrm{t}}+\eta_{\mathrm{i}, \mathrm{t}} \text {, for } \mathrm{i}=0, \ldots, \mathrm{q} \text { and } \eta_{\mathrm{i}, \mathrm{t}} \sim\left(0, \sigma_{\eta_{\mathrm{i}}}^{2}\right)
\end{aligned}
$$

As before, we tested for the random walk property using the LaMotte-McWother test. And for structural breaks, we employ the fluctuations test (Ploberger et al., 1989). Finally, we again use our general to specific approach to estimate (2.8); starting off with lag lengths of nine and $p=q$, and dropping those lags which were never significant (as we did before). ${ }^{6}$

Having estimated the coefficients in (2.8), we can calculate the gain, coherence and cross spectra based on the time-varying spectra just obtained. That allows us to overcome a major difficulty in this kind of analysis: namely that a very large number of observations would usually be necessary to carry out the necessary frequency analysis by direct estimation. This may be a particular problem in the case of structural breaks, since the sub-samples would typically be too small to allow the associated spectra to be estimated directly.

In Hughes Hallett and Richter (2002; 2003a,b; 2004, 2006, 2008) we use the fact that the timevarying cross spectrum, $f_{\mathrm{YX}}(\omega)_{\mathrm{t}}$, using the Fast Fourier Transform is given by

$$
\mathrm{f}_{\mathrm{YX}}(\omega)_{\mathrm{t}}=|\mathrm{A}(\omega)|_{\mathrm{t}} \mathrm{f}_{\mathrm{XX}}(\omega)_{\mathrm{t}}
$$

where $A(\omega)$ is the gain which is calculated using the Fast Fourier transform of the weights $\left\{a_{j}\right\}_{j=-\infty}^{\infty}$ . As noted above, the traditional formulae can be used to do this at each point in time. The last term

\footnotetext{
${ }^{6}$ The symmetry in the lag structure, and our general to specific testing strategy, means that we can allow the data to determine the direction of causality in these regressions. We find that EMU leads the individual countries (see tables 9-15). Since the reverse causalities were not accepted, we do not report coherences for those cases.
} 
in (2.9), $\mathrm{f}_{\mathrm{XX}}(\omega)_{\mathrm{t}}$, is the spectrum of the predetermined variable. Hence this spectrum may be time varying as well. Next, we calculated the gain according to

$$
|\mathrm{A}(\omega)|_{t}=\left|\sqrt{\left(\frac{\sum_{b=1}^{q} \mathrm{a}_{b, t} \exp (-j \omega b)}{1-\sum_{i=1}^{p} v_{i, t} \exp (-j \omega i)}\right)^{2}}\right|_{t}, \text { for } b=1 \ldots q \text { and } i=1 \ldots p
$$

which is time-varying as well. However in this paper we are interested in the coherence, and in the decomposition of the changes to that coherence over time. So we need to establish a link between the coherence and the gain. The spectrum of any dependent variable is defined as (Jenkins \& Watts, 1968; Laven \& Shi, 1993; Nerlove, Grether, \& Carvalho, 1995; Wolters, 1980):

$$
f_{Y Y}(\omega)_{t}=|A(\omega)|_{t} f_{X X}(\omega)_{t}+f_{V V}(\omega)_{t}
$$

where $f_{\mathrm{VV}}(\omega)_{\mathrm{t}}$ is the time-varying residual spectrum and $\mathrm{f}_{\mathrm{YY}}(\omega)_{\mathrm{t}}$ is the time varying spectrum of the endogenous variable.

Given knowledge of $f_{Y Y}(\omega)_{t},|A(\omega)|^{2}$, and $f_{X X}(\omega)_{t}$, we can now calculate the coherence as

$$
\mathrm{K}_{\mathrm{YX}, \mathrm{t}}^{2}=\frac{1}{\left\{1+\mathrm{f}_{\mathrm{VV}}(\omega)_{\mathrm{t}} /\left(|\mathrm{A}(\omega)|_{\mathrm{t}} \mathrm{f}_{\mathrm{XX}}(\omega)_{\mathrm{t}}\right)\right\}}
$$

The coherence is equivalent to the $\mathrm{R}^{2}$ of the time domain. The coherence measures, for each frequency, the degree of fit between $\mathrm{X}$ and $\mathrm{Y}$ : or the $\mathrm{R}^{2}$ between each of the corresponding cyclical components in $\mathrm{X}$ and $\mathrm{Y}$. Hence, the coherence measures the link between two variables at time $\mathrm{t}$. For example, if the coherence has a value of 0.6 at frequency 1.2, then this means that country X's business cycle at a frequency of 1.2 determines country Y's business cycle at this point in time by $60 \%$. The coherence does not take into account a shift in the business cycle, e.g. if the European business cycle leads the German one by 1 quarter. In this paper, we are concerned only with the coherence, not the gain or phase shift elements.

The next question is, in which cyclical components do structural breaks or changes in behaviour appear? We define structural changes as changes that occur in the underlying relationship between two variables. To identify such changes, we reformulate the coherence. Solving (2.11) for $f_{V v}(\omega)$, and substituting the result into (2.12), yields:

$$
\begin{aligned}
\mathrm{K}_{\mathrm{XY}, \mathrm{t}}^{2} & =\frac{1}{\left\{1+\left(\mathrm{f}_{\mathrm{YY}}(\omega)_{\mathrm{t}}-|\mathrm{A}(\omega)|_{\mathrm{t}} \mathrm{f}_{\mathrm{XX}}(\omega)_{\mathrm{t}}\right) /\left(|\mathrm{A}(\omega)|_{\mathrm{t}} \mathrm{f}_{\mathrm{XX}}(\omega)_{\mathrm{t}}\right)\right\}} \\
& =|\mathrm{A}(\omega)|_{\mathrm{t}} \frac{\mathrm{f}_{\mathrm{XX}}(\omega)_{\mathrm{t}}}{\mathrm{f}_{\mathrm{YY}}(\omega)_{\mathrm{t}}}
\end{aligned}
$$

Finally, defining

$$
\frac{f_{X X}(\omega)_{t}}{f_{Y Y}(\omega)_{t}}=f_{D D}(\omega)_{t}
$$

we get

$$
\mathrm{K}_{\mathrm{YX}, \mathrm{t}}^{2} \equiv|\mathrm{A}(\omega)|_{\mathrm{t}} \mathrm{f}_{\mathrm{DD}}(\omega)_{\mathrm{t}}
$$


This last equation, (2.15), allows us to analyse structural changes in the coherence between $\mathrm{X}$ and $\mathrm{Y}$. We can now write the changes in the coherence as:

$$
\Delta \mathrm{K}_{\mathrm{XY}, \mathrm{t}}^{2}=\Delta|\mathrm{A}(\omega)|_{\mathrm{t}} \Delta \mathrm{f}_{\mathrm{DD}}(\omega)_{\mathrm{t}}
$$

As shown in Hughes Hallett and Richter (2002; 2003a,b; 2004), (2.16) may be obtained from (2.10), (2.12), and the single variable spectra of section 2.1, (2.6), needed to generate (2.14).

Last, but not least, a note on the figures shown in the following two sections. We first present the time-varying spectra and then the coherences. One can see from these figures that the spectra change. However, one cannot infer directly from those figures that all the changes in the spectra are statistically significant. The figures for the time-varying spectra have to be accompanied by the fluctuation test results. Once a structural break has been identified by the fluctuations test, the results of that will show up as significant in the associated spectrum.

\section{Single Spectra}

In this section and the next, we study the spectra and cross-spectra of output growth in seven of the Euro area economies over the past 25 years. We use quarterly, seasonally adjusted data for real GDP in all seven economies, as published in the OECD NAQ (national Accounts quarterly) database, and then log difference them once to obtain growth rates. The resulting series were then fitted to an AR(p) model as described above, and then tested for stationarity, statistical significance and a battery of other diagnostic and specification checks. Our sample starts in 1970Q1 and finishes in 2012Q3 in each case.

We use data consistent with the ESA 95 (European System of Accounts) definitions.

\subsection{Italy}

The Italian spectrum shows very little volatility in the Italian economy at any frequency until 1999 (Figure 1). At that point, output volatility (as reflected in growth rates) doubles compared to earlier years. This volatility is concentrated on two cycles, the business cycle (3-4 year cycles) and short run cycles ( 6 months-1 year). Thus membership of the Euro seems to have disturbed the Italian economy significantly, causing either a great deal of adjustment or a great deal of being buffeted by changes and shocks that the economy was no longer able to cope with. However that effect seems to have subsided after 2003 (reform fatigue?), leaving an economy with high persistence in the longer cycles rather like France. Interestingly, the recent financial crisis increased this effect.

Before EMU there is a period of lesser volatility around 1993-7, presumably reflecting the adjustments necessary to qualify for Eurozone membership. The fact that those adjustments caused small changes relative to what came afterwards in the Euro period suggests that these reforms probably turned out to be inadequate or incomplete. The period before the Maastricht treaty shows very little volatility or change in Italian growth, except briefly at the time of German unification. During the years of the Euro, by contrast, volatility is increasing - although the density of the two most common business cycles has now returned to the values they had prior to joining the Euro. The sample period ends in 2012Q3, so it seems that Italy had "digested" the financial crisis by that stage. Indeed, Italian banks were not as affected by the financial crisis as were banks in UK or Germany. 
www.todayscience.org/jfe.php Journal of Finance and Economics Vol. 2, Issue 4, 2014

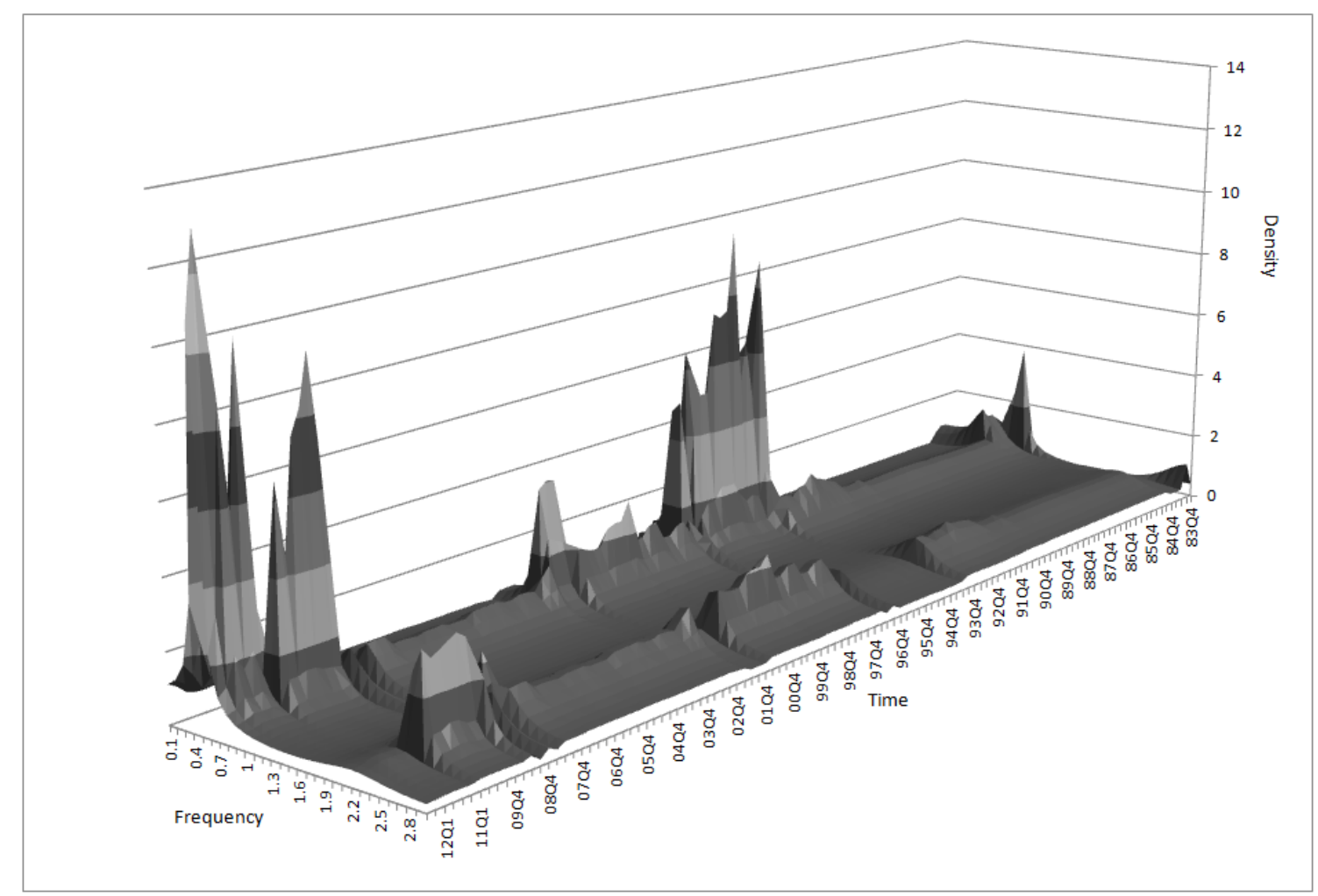

Figure 1. The Italian Spectrum

\subsection{Spain}

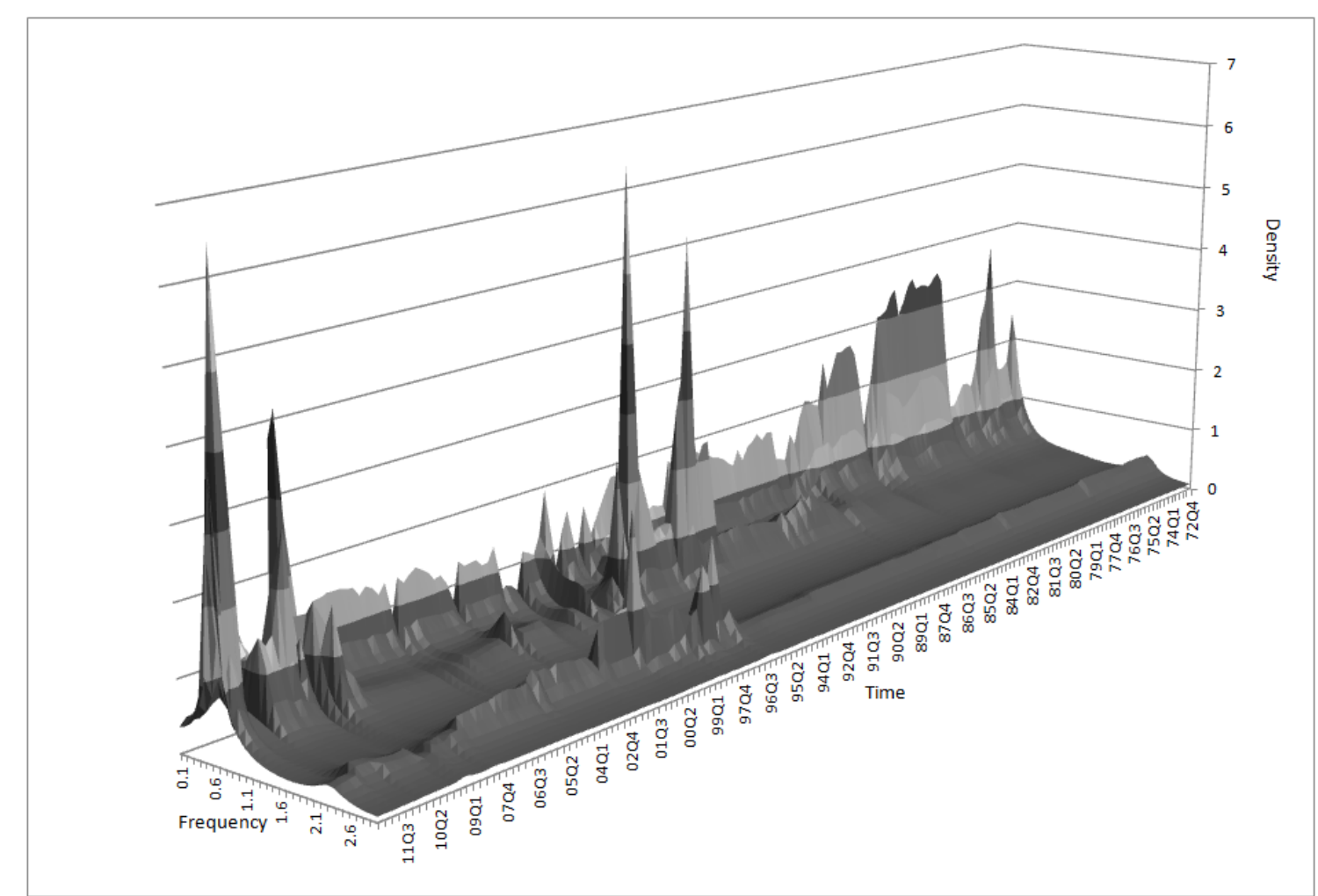

Figure 2. The Spanish Spectrum 
The main characteristics of the Italian spectrum also hold for the Spanish spectrum (Figure 2). One can observe a large volatility up to the introduction of the Euro and the first years of the Euro. The introduction of the Euro led to a different business cycle emerging; namely at a frequency of around 2.1. This business cycle was present before, but in the Euro period its density has increased a lot. This implies that its importance is grown with the Euro.

In the last two years of the sample, the long term element re-emerged as the main component of the business cycle, although its importance is still not yet as high as it used to be. Nevertheless, after the financial crisis in 2008 it emerges as the single most important cyclical component. Hence, as in Italy, the business cycle has changed back to what it was prior to joining the Euro. The financial crisis led to an increase in the importance of the long run cycles.

\subsection{Ireland}

The story for Ireland is similar to Spain and Italy (Figure 3). Prior to the introduction of the Euro, the long run trend was the most important feature of the Irish business cycle. However, short term uncertainty was also high. Once the Euro was introduced, the characteristics changed completely and the business cycle became more volatile. However, for some periods other cycles gained importance and then lost that importance again. This pattern only changed in 2009 when three new cycles emerged: at frequencies of $0.9,1.7$ and 2.5. So, as prior to the recent turmoil, the business cycle has finally converged to a less volatile state. It is worth noting that the financial crisis did not lead to an increase in the importance of the long run cycle. This aspect is completely different to Spain and Italy. It shows that the business cycle in Ireland follows a completely different pattern to the first two countries.

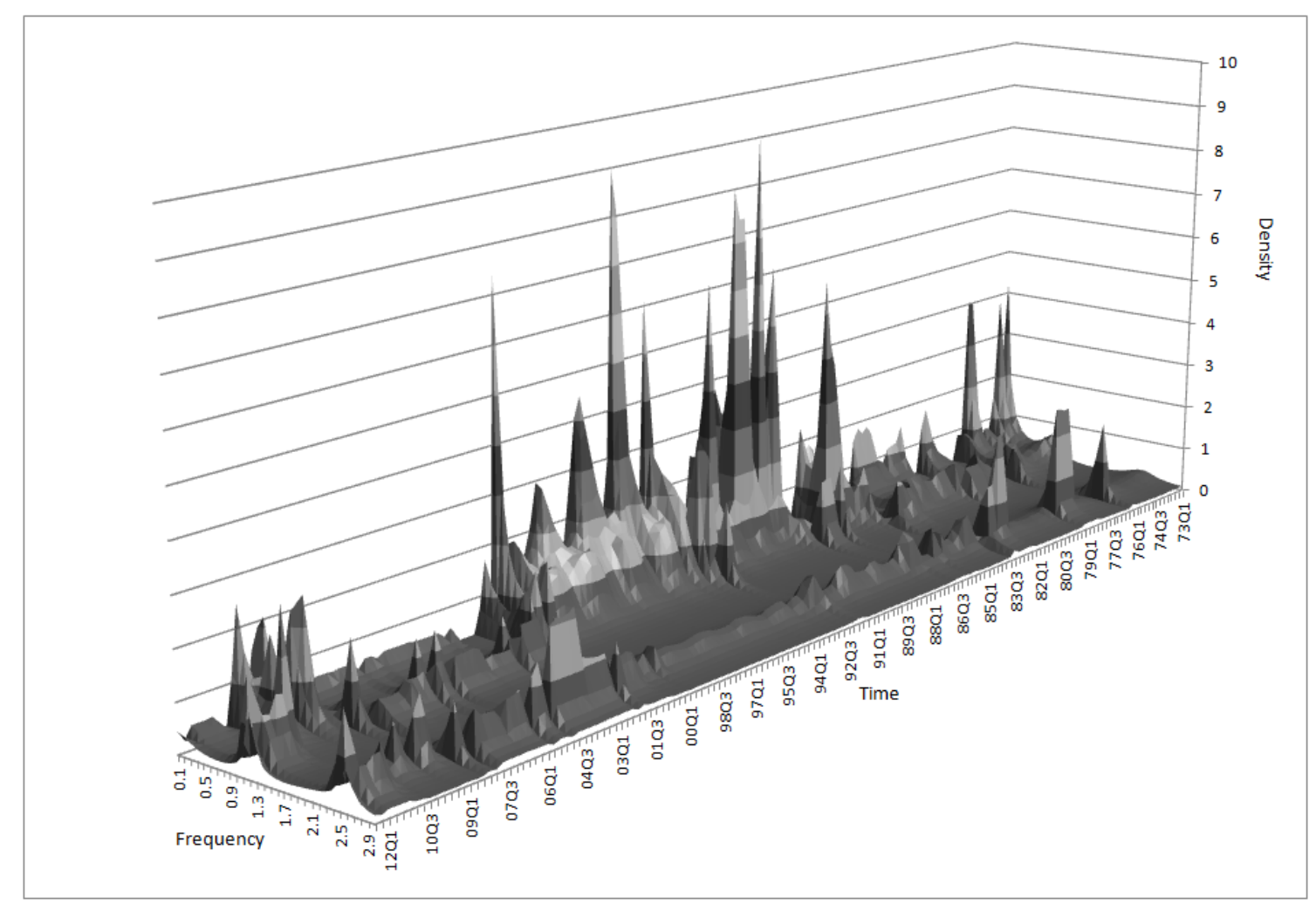

Figure 3. The Irish Spectrum 


\subsection{Portugal}

The spectrum of the Portuguese business cycle is remarkably smooth, starting in 1995 (Figure 4). Short term uncertainty is important throughout the sample, but also a cycle at a frequency of 0.6. The Portuguese economy does not seem to be affected by the financial crisis in terms of its business cycle characteristics (of course Portugal went into recession as well, but this did not change the business cycle per se). Only the EU accession in 1985 has had a perceptible impact on business cycle characteristics. As in the other cases, the Portuguese data sample ends in 2012Q3, so we cannot yet say whether the recent turmoil also had an impact on the business cycle characteristics. But what is remarkable is that up to 2012Q3 the spectrum does not indicate any expected changes. Although at the end of the sample the long run cycle gained in importance, but is less dominant than in Spain or Italy.

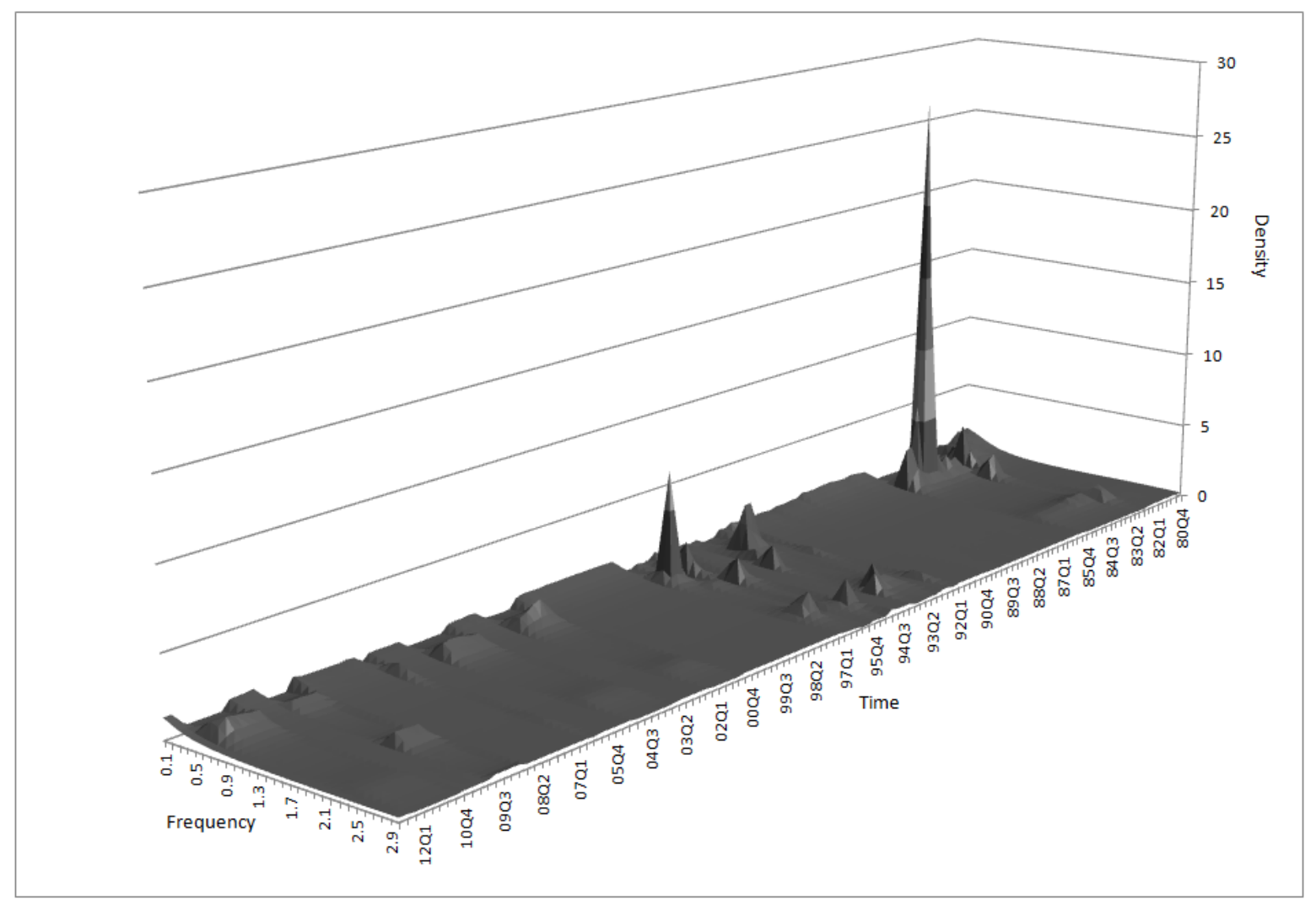

Figure 4. The Portuguese Spectrum

\subsection{Greece}

Greece is, of course, the country most affected by the recent turmoil. However, like Portugal, the Greek spectrum is fairly stable throughout the sample (Figure 5). There are periods where the Greek business cycle is volatile, for example before 1990, and then again just before the introduction of the Euro. Towards the end of the sample, however, the spectrum seems to change. This may be interpreted as the first signs of the beginning of the Greek financial problems. 


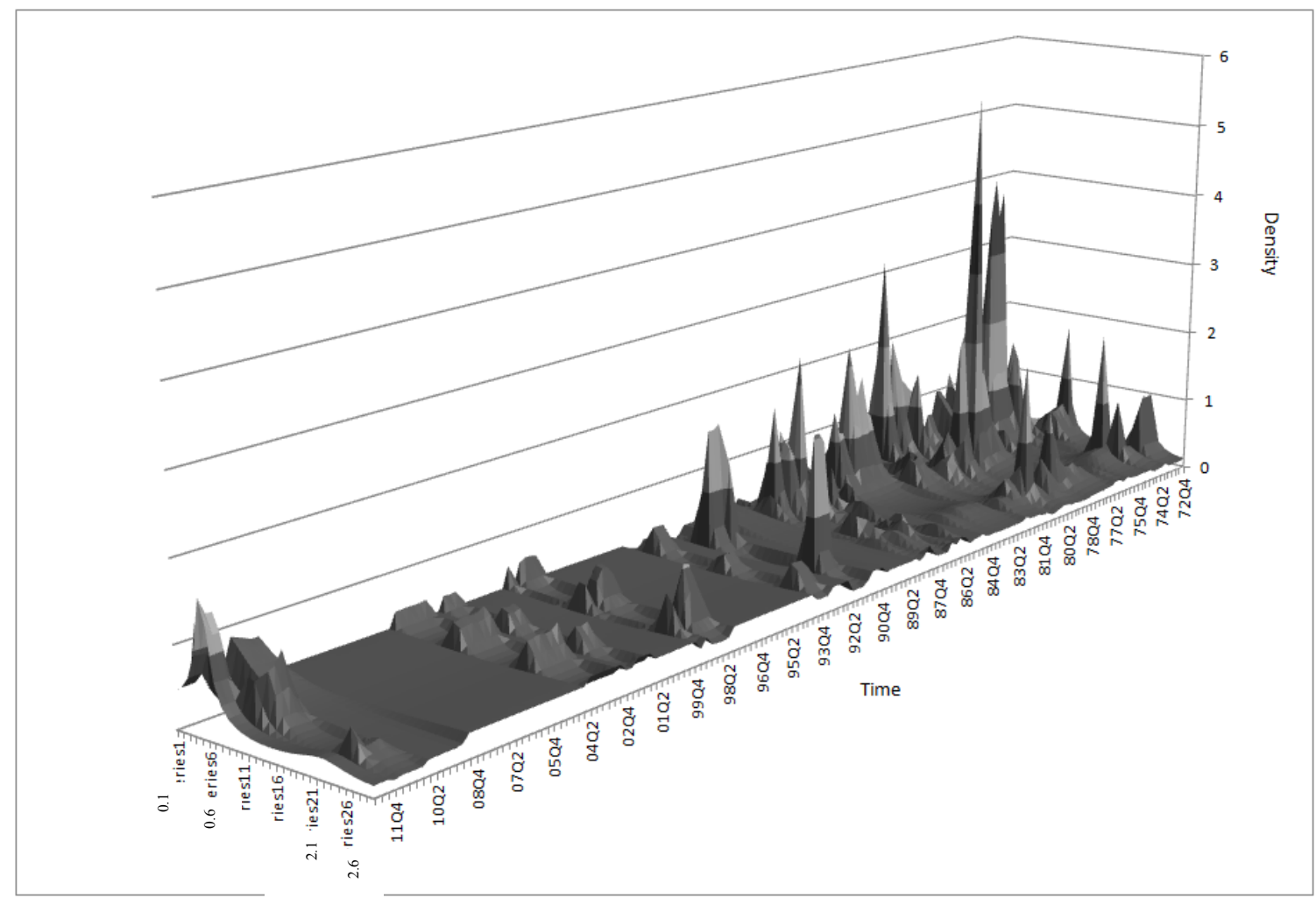

Figure 5. The Greek Spectrum

\subsection{Summary}

The individual country spectra show that the southern European countries are quite different from each other, although there are also some similarities. Greece and Portugal have in common that their business cycles were relatively calm over prolonged periods, whilst the business cycles of Spain, Ireland and Italy were much more volatile. The fact that countries still have their own business cycle characteristics confirm some results we had found earlier (Hughes Hallett \& Richter, 2006; 2008). It also highlights the fact that the source of the problems in the southern European countries is more of an individual nature than a matter of common failures. Correspondingly, there is no "one size fits all" explanation of what happened, or what the appropriate policy remedies should be. Indeed although they have unsustainable deficits in common, the source of the deficit is different from one country to another.

So, in the next section, we will look at the link between those countries and the Eurozone.

\section{Have the GIIPS Business Cycles Converged with the Rest of the Eurozone?}

We turn now to the coherence, or correlations, between the economic cycles of our Eurozone economies - and whether those coherences have been increasing or decreasing. These results will supply an informal test of the popular hypotheses that the Eurozone economies are well converged cyclically (at least better converged than with those outside the Eurozone), and whether their degree of convergence has increased with membership of the Eurozone as the European Commission and many others contend ${ }^{7}$ More specifically, we can test the proposition that, if

\footnotetext{
${ }^{7}$ See, for example, European Commission (1990), Altavilla (2004).
} 
exchange rates are pegged, then business cycles will converge as trade and financial links intensify. This is an important matter. Artis and Zhang (1997) and Frankel and Rose $(1998,2002)$ argue that this will happen as the trade and financial links strengthen; while Kalemli-Ozcan et al. (2001, 2003), Hughes Hallett and Piscitelli (2002), Baxter and Kouparitsas (2005), or Peersman and Smets (2005) show that it has not happened everywhere and may very well not happen.

This section adds empirical evidence on this issue, with the addition that we can show the frequencies at which convergence is occurring or not occurring. This extra twist is important since disagreements in the literature may have arisen because convergence has occurred at certain frequencies and not others, implying that the average correlations may have increased when the vital correlations at the business cycle frequency have gone down (or vice versa). We are principally interested in coherence at the business cycle frequency because of what it implies will be demanded of policy making and market responsiveness (and price and wage flexibility in particular); but short and long cycle coherences are important too for their ability to transmit shocks.

To assess cyclical convergence in the EU area, we take each country in our sample against the Eurozone average (rather than any particular country) since monetary policy has to be designed for that average. We then compute the coherence at different times and at different cycle lengths from the associated cross-spectra.

\subsection{Italy and the Eurozone}

We firstly investigate Italy's link with the Eurozone (Figure 6). The coherence is, in shape, more stable than Italy's spectrum; and the long run trend is the most common feature between the Eurozone and Italy.

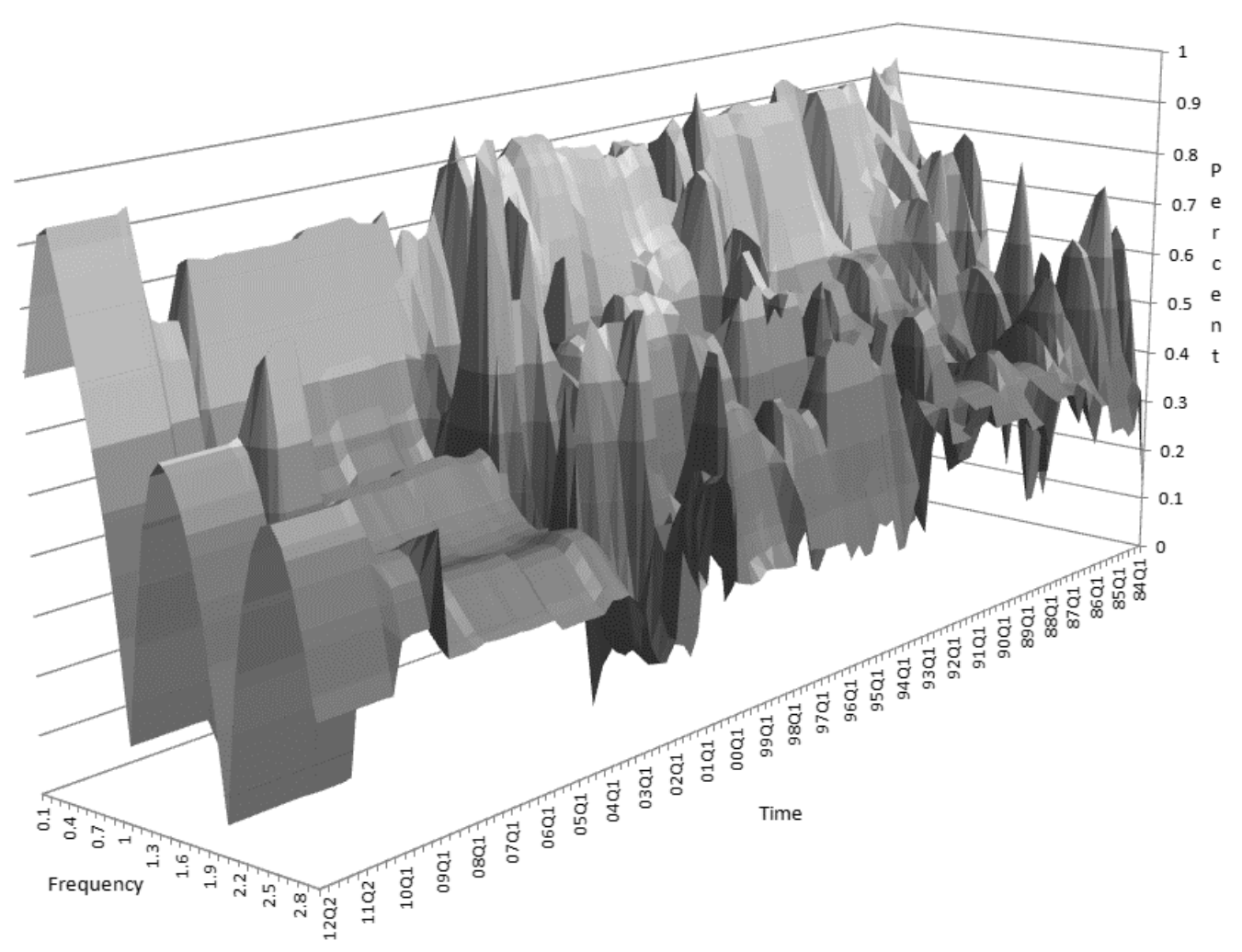

Figure 6. Coherence between Italy and the Eurozone 
At the beginning of the sample, there were mainly two cycles important to both areas: the long run trend and a cycle at around 1.3. From the beginning of the 1990s short term uncertainty became steadily more important. At the end of the sample the short run cycle had become slightly more important than the medium cycle.

Since the financial crisis in 2008, there is a recognisable shift upwards and downwards. It was reduced for the long run and short run cycles, but coherence increases for the cycle at 1.3. From 2011Q1, however, the pattern becomes much clearer. The long run and the short run cycle gain in importance, whilst the medium cycle loses a bit. Moreover, these three cycles can be explained by between $90 \%$ to $50 \%$ of the Eurozone cycles. This is still higher than at the beginning of the sample. Yet, many Italian cycles cannot be explained by the Eurozone behaviour at all. So the result is that the financial crisis since 2011 has led to a higher convergence at the long run and short run cycles. The medium cycle stabilises at around $60 \%$. However, full convergence is not achieved and the pattern has been stagnant since.

\subsection{Spain and the Eurozone}

The following Figure 7 shows the development of the coherence between Spain and the Eurozone.

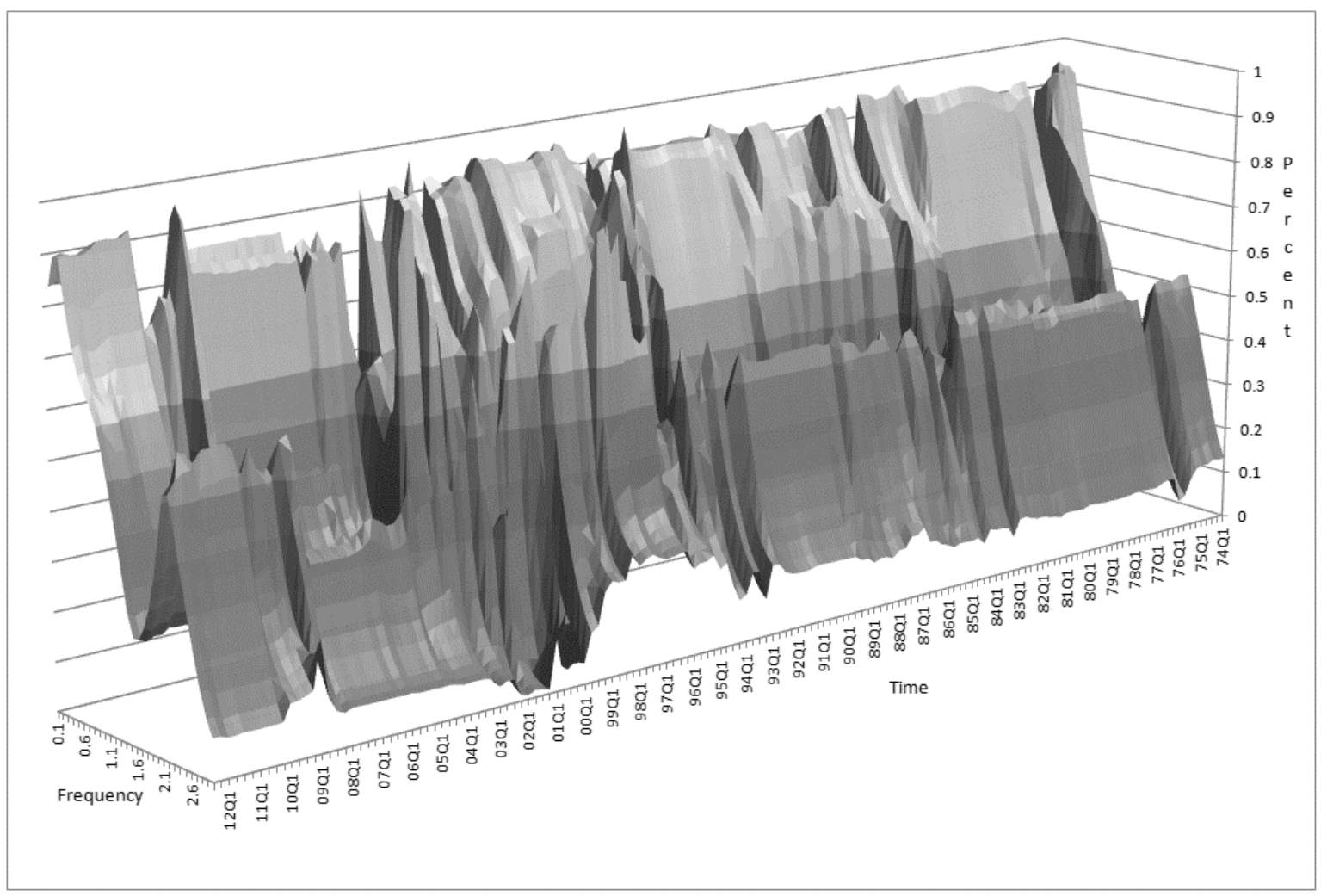

Figure 7. Coherence between Spain and the Eurozone

As in the previous case, the long run trend is the cycle which is most closely related to the Eurozone. This holds throughout the sample. The other cycle explained by the Eurozone is the short run cycle, albeit at different levels. It started off with a coherence of about $50 \%$. The period just before and after the introduction of the Euro saw coherence levels rise to around $70 \%$, and then fall to $20 \%$. The financial crisis then led to an increase to about $50 \%$ again. Interestingly, joining the Eurozone led greater uncertainty, which was removed in the early 2000s. So Eurozone 
membership has not really changed Spain's cyclical characteristics if one compares the beginning to the end of the sample. In between there was a large degree of fluctuation.

Moreover, over the entire frequency band, many cycles cannot or can only partly be explained by the Eurozone behaviour.

\subsection{Ireland and the Eurozone}

The coherence between Ireland and the Eurozone had been relatively high, up to $90 \%$, at the beginning of the sample (Figure 8). But it then declined for some cycles until 1992 when the coherence finally started to pick up again. The ERM crisis resulted in completely different business cycle characteristics which lasted until Ireland joined the Euro in 2000. The introduction of the Euro raised in particular the coherence with the Eurozone for shorter cycles.

Only when the financial crisis began in 2008 was the coherence for shorter cycles reduced, while for long cycles the coherence remained stable at a high level. However, the recent financial crisis led to an increase of the coherence for shorter cycles again. The link with the Eurozone encompasses more cycles than in Spain or Italy. In this sense, Ireland is more driven by the Eurozone than the other two countries.

It seems that only a massive outside shock can cause business cycles to converge, not the introduction of a common currency per se. Although the common currency provides a certain common basis in this case, and this was not undermined for any prolonged period.

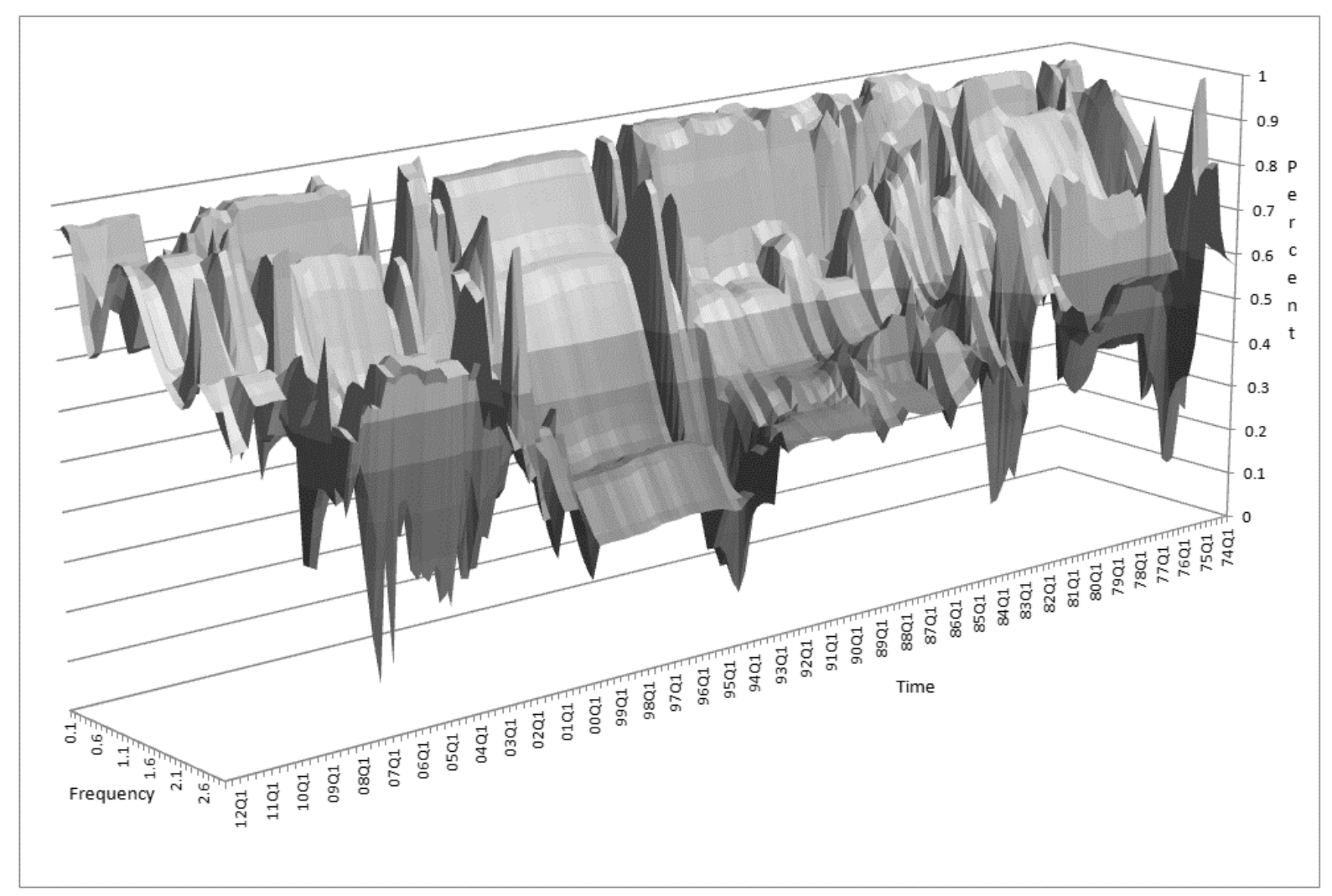

Figure 8. The coherence between Ireland and the Eurozone 


\subsection{Portugal and the Eurozone}

Even before the Euro was introduced, the Portuguese link with the Eurozone was stable for long run cycles (Figure 9). The coherence of short and medium cycles, on the other hand, is relatively low - although coherence at the shorter cycles was sometimes driven up to $40 \%$ by the Eurozone. Periodically, also, the medium cycles were also driven by the Eurozone. Thus the introduction of the Euro led to temporary changes in coherence before they moved back to their original pattern. Similarly, the financial crisis did not result in reductions of the long term coherences, but increased the coherence for shorter cycles to about $40 \%$. The non-existent medium cycle coherence was not affected. If anything the link between Portugal and the Eurozone remains stubbornly restricted to two cycles: long term and short term. The financial crisis does not seem to have changed this, nor did it lead to a higher convergence.

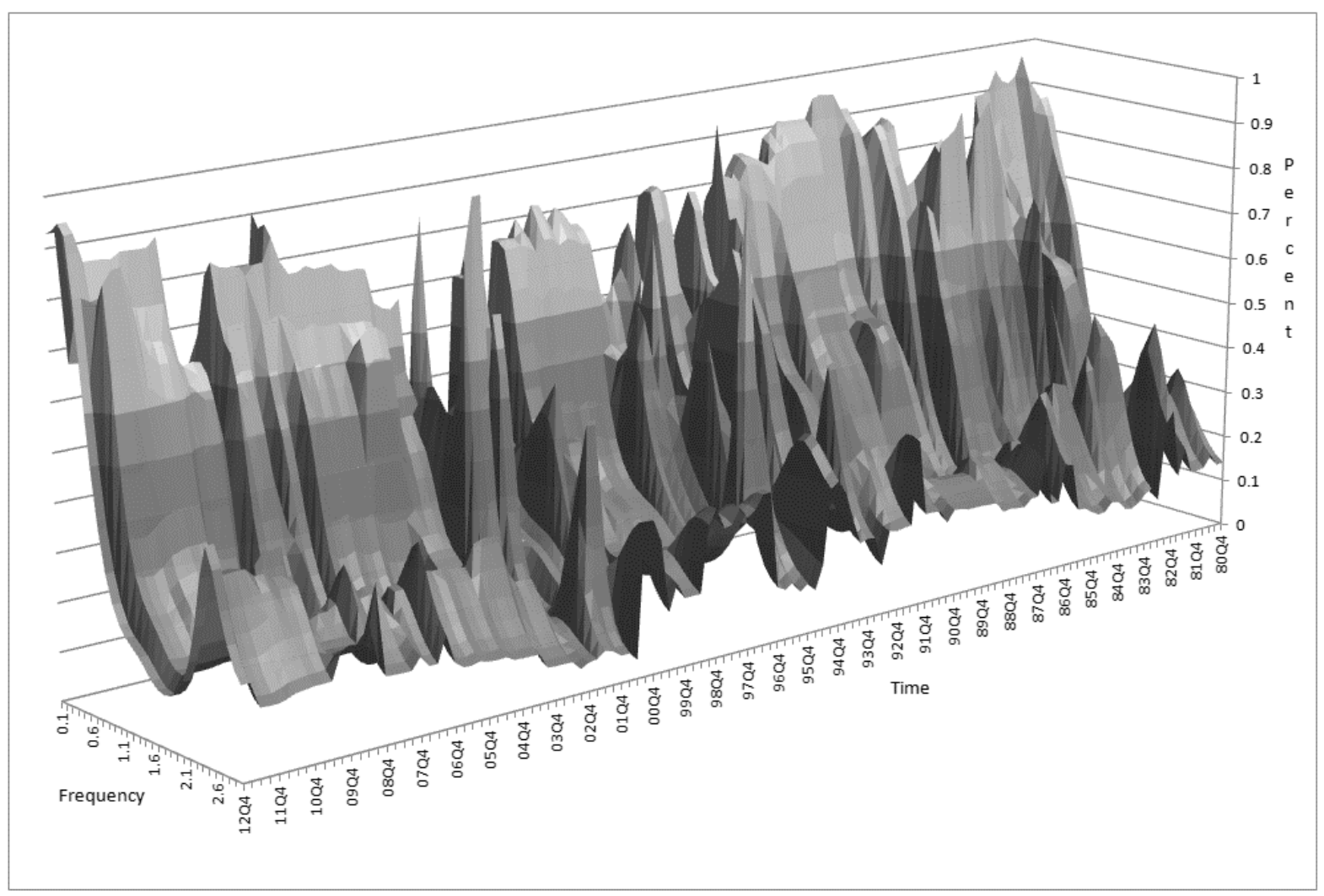

Figure 9. The coherence between Portugal and the Eurozone

\subsection{Greece and the Eurozone}

In contrast to the other countries, the coherence between Greece and the Eurozone has never been stable for a prolonged period (Figure 10). Although, there are three main links especially towards the end of the sample, at frequencies $0.3,1.6$ and 2.6. There is no convergence process visible here, but some Greek (long run) cycles are sometimes up to $90 \%$ determined by the Eurozone. The immediate reaction to the 2008 crisis was a decrease in the coherence; but this decrease was short lived. The financial crisis in 2011 led to an increase again, especially for long term and short term cycles (90\% and $50 \%$ respectively). The Euro had obviously no strong stabilising effect like in Portugal and Italy, although volatility was somewhat reduced. 


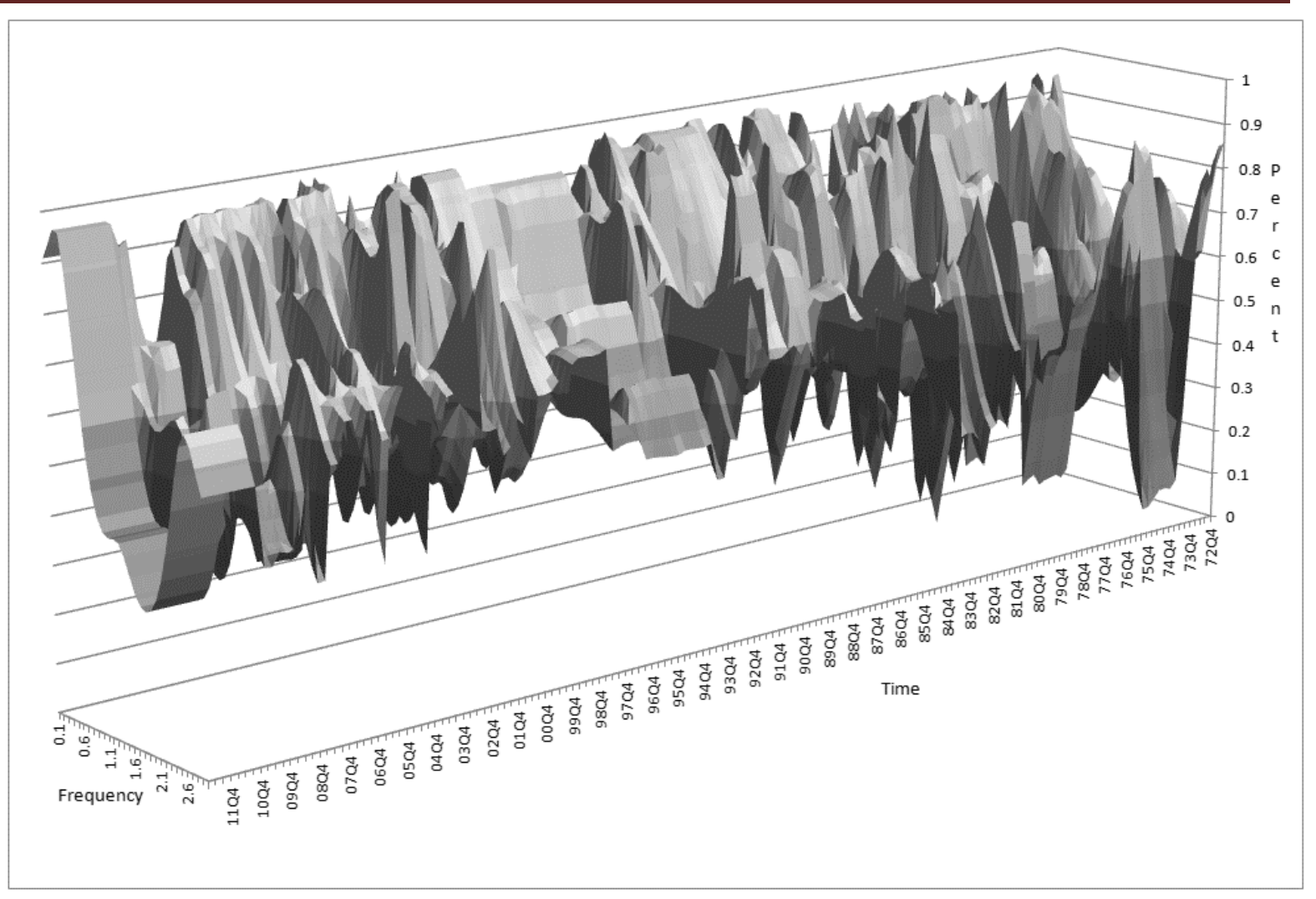

Figure 10. Coherence between Greece and the Eurozone

\section{Conclusion}

This paper has made four contributions. First we have presented a technique by which business cycles can be decomposed into their component cycles and compared; and we have shown how to do that when the component cycles, and their relative importance, are allowed to vary over time. As a result, we found that the individual data generating processes have varied across the GIIPS countries. Thus one neoclassical assumption for a common growth pattern is not fulfilled.

Second, we have shown how to extend this univariate analysis to determine the coherence between different cycles in different economies, and allow that coherence to vary over time.

Third we have shown how to apply these methods to answer the question: is there an emerging economic convergence process? As expected there is a certain amount in common between the GIIPS countries and the rest of the Eurozone; but that lies mostly in a mildly declining convergence at the business cycle frequencies, and in a shift from convergence at business cycles to a greater shared volatility (instability) at short cycles.

We find that in some cases the introduction of the Euro has not led to an increased convergence, but to a more stable relationship at the existing levels. We also found that the 2008 crisis led initially to a greater convergence for some countries which then successively reduced. The recent financial crisis led to a greater coherence at long run cycles. For Greece in particular, it seems that the initial 2008 crisis led to a decrease in Greek coherences, whilst the more recent crisis has led to an increase of those coherences. 
The conclusion from these results must be that there is no general or systematic convergence as such within the GIIPS, or between them and the Eurozone countries. Similarities or dissimilarities appear rather sporadic. Thus the introduction of the Euro is not per se a sufficient condition for convergence of business cycles. However, financial crises can change the underlying business cycle characteristics. In some cases they can cause short term convergence, but may also cause long run divergence.

\section{Acknowledgements}

We are grateful for the valuable comments of an anonymous referee which helped to improve the paper. We are also grateful for valuable comments of two anonymous referees and contributions of participants of the 12 INFER Annual Conference.

\section{References}

[1] Altavilla, C. (2004). Do EMU members share the same business cycle? Journal of Common Market Studies, 42(5), 869-896.

[2] Artis, M., Marcellino, M., \& Proietti, T. (2004). Dating the Euro area business cycle. In L. Reichlin (Ed.), The Euro area business cycle: Stylised facts and measurement issues. London, UK.: Centre for Economic Policy Research.

[3] Artis, M., \& Zhang, W. (1997). International business cycles and the ERM: Is there a European business cycle? International Journal of Finance and Economics, 2(1), 1-16.

[4] Barro, R. J., \& Sala-I-Martin, X. (1991). Convergence across states and regions. Brookings Papers on Economic Activity, 22(1), 107-182.

[5] Barro, R. J., \& Sala-I-Martin, X. (1992). Convergence. Journal of Political Economy, 100(2), 223-251.

[6] Baxter, M., \& Kouparitsas, M. A. (2005). Determinants of business cycle comovement: A Robust analysis. Journal of Monetary Economics, 52(1), 113-157.

[7] Canova, F. (1998). Detrending and business cycle facts. Journal of Monetary Economics, 41(3), 475-512.

[8] Chauvet, M., \& Potter, S. (2001). Recent changes in the US business Cycle. The Manchester School, 69(5), 481-508.

[9] Cunha, M., \& Richter, C. (2012). Measuring the impact of temperature changes on the wine production in the Douro Region using the short time Fourier transform. International Journal of Biometeorology, 56(2), 357-370.

[10] Cunha, M., \& Richter, C. (2014). A time-frequency analysis on the impact of climate variability on semi-natural mountain meadows. IEEE Transactions on Geoscience and Remote Sensing, 52(10), 6156 - 6164. doi: 10.1109/TGRS.2013.2295321.

[11] Dowrick, S., \& Nguyen, D.-T. (1989). OECD comparative economic growth 1950-85: Catchup and convergence. The American Economic Review, 79(5), 1010-1030.

[12] Doyle, B. M., \& Faust, J. (2003). Breaks in the Variability and Co-movement of G-7 Economic Growth. International Finance Discussion Paper, no 786. Washington, DC.: Board of Governors of Federal Reserve System.

[13] Evans, P., \& Karras, G. (1996). Convergence revisited. Journal of Monetary Economics, $37(2-3), 249-265$. 
[14] Frankel, J. A., \& Rose, A. K. (1998). The endogeneity of the optimal currency area criteria. Economic Journal, 108(449), 1009-1025.

[15] Gerlach, S. (1989). Information, persistence, and real business cycles. Journal of Economic Dynamics and Control, 13(2), 187-199.

[16] Harding, D., \& Pagan, A. (2001). Extracting, Analysing and Using Cyclical Information. MPRA Paper No. 15.

[17] Hughes Hallett, A., \& Richter, C. R. (2002). Are Capital Markets Efficient? Evidence from the Term Structure of Interest Rates in Europe. Economic and Social Review, 33(3), 333-356.

[18] Hughes Hallett, A., \& Richter, C. R. (2003a). Learning and monetary policy in a spectral analysis representation. In P. Wang \& S.-H. Chen (Eds.), Computational intelligence in economics and finance (pp.420-434). Berlin: Springer Verlag.

[19] Hughes Hallett, A., \& Richter, C. R. (2003b). A spectral analysis of the short-end of the British term structure. In R. Neck (Ed.), Modelling and control of economic systems (pp. 123128). Amsterdam: Elsevier.

[20] Hughes Hallett, A., \& Richter, C. R. (2004). Spectral analysis as a tool for financial policy: An analysis of the short-end of the British term structure. Computational Economics, 23(3), 271-288.

[21] Hughes Hallett, A., \& Richter, C. R. (2006). Measuring the degree of convergence among European business cycles. Computational Economics, 27(2-3), 229-259.

[22] Hughes Hallett, A., \& Richter, C. R. (2008). Have the Eurozone economies converged on to a common European cycle? International Economics and Economic Policy, 5(1-2), 71-101.

[23] Inklaar, R., \& de Haan, J. (2000). Is there really a European business cycle? CESifo Working Paper, No. 268.

[24] Jenkins, G. M., \& Watts, D. G. (1968). Spectral Analysis and its Applications. San Francisco: Holden-Day.

[25] Kalemli-Ozcan, S., Sorensen, B., \& Yosha, O. (2001). Economic integration, industrial specialisation, and the asymmetry of macroeconomic fluctuations. Journal of International Economics, 55(1), 107-137.

[26] LaMotte, L. R., \& McWorther Jr., A. (1978). An exact test for the presence of random walk coefficients in a linear regression model. Journal of the American Statistical Association, 73(364), 816-820.

[27] Laven, G., \& Shi, G. (1993). Zur interpretation von lagverteilungen. Mainz Johannes Gutenberg University Discussion Paper, No. 41.

[28] Lin, Z. (1997). An introduction to time-frequency signal analysis. Sensor Review, 17(1), 46-53.

[29] Mankiw, N. G., Romer, D., \& Weil, D. N. (1992). A contribution to the empirics of economic growth. Quarterly Journal of Economics, 107(2), 407-437.

[30] Matz, G., \& Hlawatsch, F. (2003). Time-varying power spectra of nonstationary random processes. In B. Boashash (Ed.), Time-frequency signal analysis and processing (pp.400408). Amsterdam: Elsevier.

[31] Nerlove, M., Grether, D. M., \& Carvalho, J. L. (1995). Analysis of economic time series: A synthesis (Revised ed.). New York: Academic Press.

[32] Peersman, G., \& Smets, F. R. (2005). Industry effects of monetary policy in the Euro Area. Economic Journal, 115(504), 319-342. 
[33] Ploberger, W., Krämer, W., \& Kontrus, K. (1989). A new test for structural stability in the linear regression model. Journal of Econometrics, 40(2), 307-318.

[34] Quah, D. T. (1993). Galton's Fallacy and Tests of the Convergence Hypothesis. Scandinavian Journal of Economics, 95(4), 427-443.

[35] Söderlind, P. (1994). Cyclical properties of a real business cycle model. Journal of Applied Econometrics, 9(S1), S113-S122.

[36] Stock, J. H., \& Watson, M. W. (2002). Has the business cycle changed and why? NBER Working paper, No 9127.

[37] Stock, J. H., \& Watson, M. W. (2003). Understanding changes in the international business cycle dynamics. NBER Working paper, No 9859.

[38] Wells, C. (1996). The Kalman filter in finance. Dordrecht: Kluwer Academic Publishers.

[39] Wolff, E. N. (1991). Capital formation and productivity convergence over the long term. The American Economic Review, 81(3), 565-579.

[40] Wolters, J. (1980). Stochastic dynamic properties of linear econometric models. Berlin: Springer Verlag.

\section{Appendix 1: The Statistical Results}

Note: For reasons of space, the results quoted in the tables describe the final regression done and its diagnostic tests. But the figures below display the period by period spectral results implied by the underlying time-varying regressions.

Table 1. Italian regression results

\begin{tabular}{|c|c|c|c|}
\hline \multicolumn{4}{|c|}{ VAR/System - Estimation by Kalman Filter } \\
\hline Dependent Variable & DLITGDP & Quarterly Data From & 1982:01 To 2012:03 \\
\hline Usable Observations & 123 & Degrees of Freedom & 118 \\
\hline Uncentered $\mathrm{R}^{2}$ & 0.9989 & & \\
\hline $\begin{array}{l}\text { Mean of Dependent } \\
\text { Variable }\end{array}$ & 1.3512 & $\begin{array}{l}\text { Std Error of } \\
\text { Dependent Variable }\end{array}$ & 2.0235 \\
\hline $\begin{array}{l}\text { Standard Error of } \\
\text { Estimate }\end{array}$ & 1.7594 & & \\
\hline $\begin{array}{l}\text { Akaike Information } \\
\text { Criterion: }\end{array}$ & 0.0049 & $\begin{array}{l}\text { Ljung-Box Test: } \\
\mathrm{Q}^{*}(21)=\end{array}$ & 25.2520 \\
\hline Variable & Coeff & Std Error & T-Stat \\
\hline Constant & -0.3777 & 12.9159 & -0.0292 \\
\hline DLITGDP $\{1\}$ & 0.6942 & 0.3559 & 1.9507 \\
\hline DLITGDP $\{3\}$ & 0.1957 & 0.2803 & 0.6981 \\
\hline DLITGDP $\{4\}$ & -0.4994 & 0.1873 & -2.6668 \\
\hline DLITGDP $\{7\}$ & -0.0524 & 0.0398 & -1.3142 \\
\hline
\end{tabular}


www.todayscience.org/jfe.php Journal of Finance and Economics Vol. 2, Issue 4, 2014

Table 2. Regression results between Italy and EMU

\begin{tabular}{|c|c|c|c|}
\hline \multicolumn{4}{|c|}{ VAR/System - Estimation by Kalman Filter } \\
\hline Dependent Variable & DLITGDP & Quarterly Data From & 1982:01 Тo 2012:03 \\
\hline Usable Observations & 123 & Degrees of Freedom & 114 \\
\hline Uncentered $\mathrm{R}^{2}$ & 0.9907 & & \\
\hline $\begin{array}{l}\text { Mean of Dependent } \\
\text { Variable }\end{array}$ & 1.3512 & $\begin{array}{l}\text { Std Error of } \\
\text { Dependent Variable }\end{array}$ & 2.0235 \\
\hline $\begin{array}{l}\text { Standard Error of } \\
\text { Estimate }\end{array}$ & 2.0575 & & \\
\hline $\begin{array}{l}\text { Akaike Information } \\
\text { Criterion: }\end{array}$ & 0.04479 & $\begin{array}{l}\text { Ljung-Box Test: } \\
Q^{*}(22)=\end{array}$ & 31.2179 \\
\hline Variable & Coeff & Std Error & T-Stat \\
\hline Constant & -1.2449 & 2.2377 & -0.5564 \\
\hline DLITGDP $\{3\}$ & 0.1107 & 0.0177 & 6.2538 \\
\hline DLITGDP $\{7\}$ & -0.1799 & 0.2912 & -0.6179 \\
\hline DLEMUITGDP & 0.7787 & 0.0876 & 8.8867 \\
\hline DLEMUITGDP $\{1\}$ & 0.1464 & 0.0419 & 3.4913 \\
\hline DLEMUITGDP $\{2\}$ & 0.0572 & 0.0861 & 0.6639 \\
\hline DLEMUITGDP $\{4\}$ & -0.2948 & 0.3276 & -0.8998 \\
\hline DLEMUITGDP $\{6\}$ & -0.0138 & 0.2464 & -0.0561 \\
\hline DLEMUITGDP $\{7\}$ & -0.0067 & 0.2396 & -0.0279 \\
\hline
\end{tabular}

Table 3. Spanish regression results

\begin{tabular}{|c|c|c|c|}
\hline \multicolumn{4}{|c|}{ VAR/System - Estimation by Kalman Filter } \\
\hline Dependent Variable & DLSPGDP & Quarterly Data From & 1970:01 Тo $2012: 03$ \\
\hline Usable Observations & 163 & Degrees of Freedom & 156 \\
\hline Uncentered $\mathrm{R}^{2}$ & 0.9998 & & \\
\hline $\begin{array}{l}\text { Mean of Dependent } \\
\text { Variable }\end{array}$ & 8.5115 & $\begin{array}{l}\text { Std Error of } \\
\text { Dependent Variable }\end{array}$ & 6.7422 \\
\hline $\begin{array}{l}\text { Standard Error of } \\
\text { Estimate }\end{array}$ & 7.9416 & & \\
\hline $\begin{array}{l}\text { Akaike Information } \\
\text { Criterion: }\end{array}$ & 0.0157 & $\begin{array}{l}\text { Ljung-Box Test: } \\
Q^{*}(25)=\end{array}$ & 34.5025 \\
\hline Variable & Coeff & Std Error & T-Stat \\
\hline Constant & -0.1985 & 0.1081 & -1.8366 \\
\hline DLSPGDP $\{1\}$ & 1.0618 & 0.1422 & 7.4683 \\
\hline DLSPGDP $\{2\}$ & -0.4709 & 0.1332 & -3.5349 \\
\hline $\operatorname{DLSPGDP}\{3\}$ & 0.1151 & 0.2134 & 0.5395 \\
\hline $\operatorname{DLSPGDP}\{4\}$ & -0.6058 & 0.0617 & -9.8178 \\
\hline $\operatorname{DLSPGDP}\{5\}$ & 0.4349 & 0.0852 & 5.1013 \\
\hline $\operatorname{DLSPGDP}\{6\}$ & -0.2381 & 0.1200 & -1.9841 \\
\hline
\end{tabular}


Table 4. Regression results between Spain and EMU

\begin{tabular}{|c|c|c|c|}
\hline \multicolumn{4}{|c|}{ VAR/System - Estimation by Kalman Filter } \\
\hline Dependent Variable & DLSPGDP & Quarterly Data From & 1970:01 To $2012: 03$ \\
\hline Usable Observations & 163 & Degrees of Freedom & 152 \\
\hline Uncentered $\mathrm{R}^{2}$ & 0.99917 & & \\
\hline $\begin{array}{l}\text { Mean of Dependent } \\
\text { Variable }\end{array}$ & 8.5115 & $\begin{array}{l}\text { Std Error of } \\
\text { Dependent Variable }\end{array}$ & 6.7422 \\
\hline Standard Error of Estimate & 2.8036 & & \\
\hline $\begin{array}{l}\text { Akaike Information } \\
\text { Criterion: }\end{array}$ & 0.0403 & $\begin{array}{l}\text { Ljung-Box Test: } \\
Q^{*}(25)=\end{array}$ & 37.1018 \\
\hline Variable & Coeff & Std Error & T-Stat \\
\hline Constant & 0.0265 & 0.1148 & 0.2311 \\
\hline $\operatorname{DLSPGDP}\{1\}$ & 0.6833 & 0.0073 & 94.1612 \\
\hline $\operatorname{DLSPGDP}\{2\}$ & -0.1853 & 0.0728 & -2.5449 \\
\hline $\operatorname{DLSPGDP}\{3\}$ & 0.3853 & 0.1115 & 3.4559 \\
\hline $\operatorname{DLSPGDP}\{4\}$ & -0.4485 & 0.0931 & -4.819 \\
\hline $\operatorname{DLSPGDP}\{5\}$ & 0.3882 & 0.1177 & 3.2972 \\
\hline DLSPGDP $\{6\}$ & -0.0789 & 0.1037 & -0.7605 \\
\hline DLEMUSPGDP & 0.3545 & 0.1233 & 2.8756 \\
\hline DLEMUSPGDP $\{4\}$ & -0.0894 & 0.0340 & -2.6280 \\
\hline DLEMUSPGDP $\{5\}$ & -0.0927 & 0.0941 & -0.9856 \\
\hline DLEMUSPGDP $\{6\}$ & -0.0993 & 0.0780 & -1.2732 \\
\hline
\end{tabular}

Table 5. Regression results for Ireland

\begin{tabular}{|c|c|c|c|}
\hline \multicolumn{4}{|c|}{ VAR/System - Estimation by Kalman Filter } \\
\hline Dependent Variable & DLIRGDP & Quarterly Data From & 1972:01 Тo 2012:03 \\
\hline Usable Observations & 163 & Degrees of Freedom & 157 \\
\hline Uncentered $\mathrm{R}^{2}$ & 0.9990 & & \\
\hline $\begin{array}{l}\text { Mean of Dependent } \\
\text { Variable }\end{array}$ & 3.9942 & $\begin{array}{l}\text { Std Error of } \\
\text { Dependent Variable }\end{array}$ & 3.6935 \\
\hline $\begin{array}{l}\text { Standard Error of } \\
\text { Estimate }\end{array}$ & 4.6822 & & \\
\hline $\begin{array}{l}\text { Akaike Information } \\
\text { Criterion: }\end{array}$ & 0.0144 & $\begin{array}{l}\text { Ljung-Box Test: } \\
\mathrm{Q}^{*}(26)=\end{array}$ & 33.8447 \\
\hline Variable & Coeff & Std Error & T-Stat \\
\hline Constant & -0.3384 & 1.8965 & -0.1784 \\
\hline $\operatorname{DLIRGDP}\{1\}$ & 0.4409 & 0.5699 & 0.7736 \\
\hline $\operatorname{DLIRGDP}\{4\}$ & -0.5959 & 0.3852 & -1.5469 \\
\hline $\operatorname{DLIRGDP}\{5\}$ & 0.6253 & 0.0445 & 14.0482 \\
\hline $\operatorname{DLIRGDP}\{7\}$ & -0.0415 & 0.0798 & -0.5207 \\
\hline $\operatorname{DLIRGDP}\{8\}$ & -0.2496 & 0.0467 & -5.2002 \\
\hline
\end{tabular}


www.todayscience.org/jfe.php Journal of Finance and Economics Vol. 2, Issue 4, 2014

Table 6. Regression results between Ireland and the EMU

\begin{tabular}{|c|c|c|c|}
\hline \multicolumn{4}{|c|}{ VAR/System - Estimation by Kalman Filter } \\
\hline Dependent Variable & DLIRGDP & Quarterly Data From & 1972:01 To 2012:03 \\
\hline Usable Observations & 163 & Degrees of Freedom & 154 \\
\hline Uncentered $\mathrm{R}^{2}$ & 0.9893 & & \\
\hline $\begin{array}{l}\text { Mean of Dependent } \\
\text { Variable }\end{array}$ & 3.9942 & $\begin{array}{l}\text { Std Error of } \\
\text { Dependent Variable }\end{array}$ & 3.6935 \\
\hline Standard Error of Estimate & 3.2238 & & \\
\hline $\begin{array}{l}\text { Akaike Information } \\
\text { Criterion: }\end{array}$ & 0.1549 & $\begin{array}{l}\text { Ljung-Box Test: } \\
Q^{*}(25)=\end{array}$ & 36.6505 \\
\hline Variable & Coeff & Std Error & T-Stat \\
\hline Constant & -1.6113 & 0.2746 & -5.8676 \\
\hline DLIRGDP $\{1\}$ & 0.0263 & 0.3987 & 0.0659 \\
\hline $\operatorname{DLIRGDP}\{2\}$ & 0.1438 & 0.3274 & 0.4391 \\
\hline $\operatorname{DLIRGDP}\{4\}$ & -0.2784 & 0.3200 & -0.8701 \\
\hline $\operatorname{DLIRGDP}\{5\}$ & 0.3230 & 0.0187 & 17.2303 \\
\hline DLEMUIRGDP & 1.6194 & 0.3360 & 4.8202 \\
\hline DLEMUIRGDP $\{2\}$ & -0.5867 & 0.1838 & -3.1928 \\
\hline DLEMUIRGDP $\{4\}$ & 0.7087 & 0.2456 & 2.8855 \\
\hline DLEMUIRGDP $\{6\}$ & 0.2259 & 0.1691 & 1.3358 \\
\hline
\end{tabular}

Table 7. Regession results for Portugal

\begin{tabular}{|c|c|c|c|}
\hline \multicolumn{4}{|c|}{ VAR/System - Estimation by Kalman Filter } \\
\hline Dependent Variable & DLPTGDP & Quarterly Data From & 1979:01 Тo 2012:04 \\
\hline Usable Observations & 136 & Degrees of Freedom & 131 \\
\hline Uncentered $\mathrm{R}^{2}$ & 0.9500 & & \\
\hline $\begin{array}{l}\text { Mean of Dependent } \\
\text { Variable }\end{array}$ & 1.8006 & $\begin{array}{l}\text { Std Error of } \\
\text { Dependent Variable }\end{array}$ & 2.8661 \\
\hline $\begin{array}{l}\text { Standard Error of } \\
\text { Estimate }\end{array}$ & 2.3078 & & \\
\hline $\begin{array}{l}\text { Akaike Information } \\
\text { Criterion: }\end{array}$ & 0.4339 & $\begin{array}{l}\text { Ljung-Box Test: } \\
Q^{*}(26)=\end{array}$ & 33.2749 \\
\hline Variable & Coeff & Std Error & T-Stat \\
\hline Constant & -1.0801 & 1.2721 & -0.8491 \\
\hline $\operatorname{DLPTGDP}\{1\}$ & 0.5598 & 0.1064 & 5.2631 \\
\hline DLPTGDP $\{2\}$ & 0.1902 & 0.0405 & 4.7004 \\
\hline DLPTGDP $\{4\}$ & -0.3258 & 0.2196 & -1.4837 \\
\hline DLPTGDP $\{5\}$ & 0.3261 & 0.4629 & 0.7044 \\
\hline
\end{tabular}


Table 8. Regression results between Portugal and the Eurozone

\begin{tabular}{||l|l|l|l||}
\hline \multicolumn{5}{|c|}{ VAR/System - Estimation by Kalman Filter } \\
\hline Dependent Variable & \multicolumn{1}{|l||}{ DLPTGDP } & Quarterly Data From & $1979: 01$ To 2012:04 \\
\hline Usable Observations & 136 & Degrees of Freedom & 129 \\
\hline Uncentered R ${ }^{2}$ & 0.9380 & & \\
\hline Mean of Dependent Variable & 1.8006 & $\begin{array}{l}\text { Std Error of } \\
\text { Dependent Variable }\end{array}$ & 2.8661 \\
\hline Standard Error of Estimate & 1.9804 & & \\
\hline $\begin{array}{l}\text { Akaike Information } \\
\text { Criterion: }\end{array}$ & 0.5201 & $\begin{array}{l}\text { Ljung-Box Test: } \\
\text { Q*(22) }\end{array}$ & 32.7524 \\
\hline Variable & Coeff & Std Error & T-Stat \\
\hline Constant & -0.4710 & 0.4275 & -1.1017 \\
\hline DLPTGDP $\{1\}$ & 0.5706 & 0.1379 & 4.1373 \\
\hline DLPTGDP $\{2\}$ & 0.6939 & 0.4179 & 1.6602 \\
\hline DLPTGDP $\{4\}$ & -0.5973 & 0.1928 & -3.0984 \\
\hline DLPTGDP $\{5\}$ & 0.1924 & 0.0199 & 9.6730 \\
\hline DLEMUPTGDP & 0.2137 & 0.0429 & 4.9793 \\
\hline DLEMUPTGDP $\{2\}$ & 0.0430 & 0.0365 & 1.1791 \\
\hline \hline
\end{tabular}

Table 9. Regression results for Greece

\begin{tabular}{|c|c|c|c|}
\hline \multicolumn{4}{|c|}{ VAR/System - Estimation by Kalman Filter } \\
\hline Dependent Variable & DLGRGDP & Quarterly Data From & 1972:01 To 2012:03 \\
\hline Usable Observations & 163 & Degrees of Freedom & 157 \\
\hline Uncentered $\mathrm{R}^{2}$ & 0.9727 & & \\
\hline $\begin{array}{l}\text { Mean of Dependent } \\
\text { Variable }\end{array}$ & 1.9388 & $\begin{array}{l}\text { Std Error of } \\
\text { Dependent Variable }\end{array}$ & 3.9269 \\
\hline $\begin{array}{l}\text { Standard Error of } \\
\text { Estimate }\end{array}$ & 3.1293 & & \\
\hline $\begin{array}{l}\text { Akaike Information } \\
\text { Criterion: }\end{array}$ & 0.4694 & $\begin{array}{l}\text { Ljung-Box Test: } \\
Q^{*}(25)=\end{array}$ & 31.8772 \\
\hline Variable & Coeff & Std Error & T-Stat \\
\hline Constant & -0.4997 & 1.5130 & -0.3303 \\
\hline DLGRGDP $\{1\}$ & 0.6968 & 0.2300 & 3.0298 \\
\hline DLGRGDP $\{2\}$ & 0.0848 & 0.0197 & 4.3171 \\
\hline DLGRGDP $\{4\}$ & -0.4118 & 0.2329 & -1.7687 \\
\hline $\operatorname{DLGRGDP}\{5\}$ & 0.3907 & 0.3346 & 1.1677 \\
\hline DLGRGDP $\{6\}$ & -0.2677 & 0.3158 & -0.8478 \\
\hline
\end{tabular}


www.todayscience.org/jfe.php Journal of Finance and Economics Vol. 2, Issue 4, 2014

Table 10. Regression results for Greece and the Eurozone

\begin{tabular}{|c|c|c|c|}
\hline \multicolumn{4}{|c|}{ VAR/System - Estimation by Kalman Filter } \\
\hline Dependent Variable & DLGRGDP & Quarterly Data From & 1972:01 To 2012:03 \\
\hline Usable Observations & 163 & Degrees of Freedom & 155 \\
\hline Uncentered $\mathrm{R}^{2}$ & 0.9842 & & \\
\hline $\begin{array}{l}\text { Mean of Dependent } \\
\text { Variable }\end{array}$ & 1.9388 & $\begin{array}{l}\text { Std Error of } \\
\text { Dependent Variable }\end{array}$ & 3.9269 \\
\hline Standard Error of Estimate & 3.8720 & & \\
\hline $\begin{array}{l}\text { Akaike Information } \\
\text { Criterion: }\end{array}$ & 0.2718 & $\begin{array}{l}\text { Ljung-Box Test: } \\
Q^{*}(25)=\end{array}$ & 25.7495 \\
\hline Variable & Coeff & Std Error & T-Stat \\
\hline Constant & -1.0217 & 1.8651 & -0.5478 \\
\hline $\operatorname{DLGRGDP}\{1\}$ & 0.1312 & 0.0233 & 5.6337 \\
\hline DLGRGDP $\{2\}$ & 0.7300 & 0.4899 & 1.4901 \\
\hline DLGRGDP $\{4\}$ & -0.2679 & 0.2282 & -1.174 \\
\hline DLGRGDP $\{6\}$ & 0.0759 & 0.1224 & 0.6197 \\
\hline DLEMUGRGDP & 0.5278 & 0.0841 & 6.2756 \\
\hline DLEMUGRGDP $\{2\}$ & 0.0775 & 0.4680 & 0.1655 \\
\hline DLEMUGRGDP $\{6\}$ & 0.8581 & 0.5878 & 1.4599 \\
\hline
\end{tabular}

\section{Copyrights}

Copyright for this article is retained by the author(s), with first publication rights granted to the journal. This is an open-access article distributed under the terms and conditions of the Creative Commons Attribution 4.0 International License.

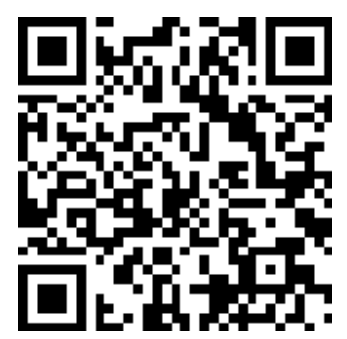

